\title{
Conceptual Dynamism and Ambiguity in Marrangu Djinang Cosmology, North-Central Arnhem Land
}

\section{Introduction}

In a 1977 conference paper, 'Ambiguity in Yolngu Religious Language', Keen identified conceptual ambiguity as a critical cultural mechanism by which economies of knowledge and local group identities are reproduced in Arnhem Land thought and social life. The ethnographic interpretation of Yolngu conceptual indeterminancy produced a rich preoccupation in Keen's scholarship. This and related subjects were elaborated in his PhD thesis, 'One Ceremony, One Song' (1978), Knowledge and Secrecy in an Aboriginal Religion (1994) and in 'Metaphor and the Metalanguage' (1995). The 1977 paper highlighted the role of song language, within shared mythologies, in the process of creating difference amidst underlying socio-religious sameness (1977: 33). His thesis examined how a 'same song' interpretive technique both links and differentiates ownership of religious sacra in Yolngu belief and ceremonial practice (1978: 210-15; 1994: 132-64). These sources significantly contribute to understanding how constructs in the religious domain create and distribute social meanings in the Arnhem Land landscape, themes this paper pursues. 
It is well recognised that cosmological and social classificatory systems routinely contain indeterminacies and ambiguities (Keen 1995: 507). In Arnhem Land cosmologies, little sociolinguistic distinction is made between corporeal and incorporeal entities (see Keen 1978: 42). Nor are sharp distinctions made about the conceptual aspects and boundaries of cosmological categoriesanthropomorphic spirit beings, for example. It is therefore not surprising that many motifs convey a range of significations through analogy. Meaningful cultural interpretations are not entirely open-ended, but cued and referenced by local mythological, environmental, ceremonial and social contexts. For these reasons, while still noting that typologies exist, Keen rightly cautions against the categorisation of Arnhem Land spirit beings using 'unequivocal criteria' (1994: 45).

For Marrangu Djinang cosmology in north-central Arnhem Land, Borsboom (1978a, 1978b, 2011) and I (1991) have provided ethnographic evidence and analyses highlighting similar reservations. Specifically regarding the representation of $\mathrm{Merri}^{1}$ and Mewal, two anthropomorphic spirit beings in Marrangu Djinang cosmology, there are richly multilayered and ambiguous significations at work. This paper first outlines Marrangu Djinang sociality, focusing on land and Arnhem Land local organisation, with reference to Keen's (1995) critique of that subject. The paper then employs a strongly local ethnographic perspective to describe and explain overlapping and ambiguous attributes of Merri and Mewal. The paper focuses on Merri and Mewal's importance in the local environment and in Marrangu Djinang cosmology, song, ceremony, and mortality and affliction beliefs. The analysis proceeds with Keen's caution concerning unequivocal analytical categorisation of Yolngu ontological concepts firmly in mind.

\section{Marrangu Djinang Land and Identity}

The physical environment of north-central Arnhem Land is dominated by dry eucalyptus forest and Darwin stringybark (Eucalyptus tetradonta) in particular. The eucalypt forests of Marrangu Djinang country are drained by two watercourses, Djimbi and Gattji Creeks. North of the forest areas are seasonally flooding and semi-tidal lowlands. Here Gattji and Djimbi Creeks peter out: the former into a series of swamps; the latter into a jungle waterhole. Mangrove-lined saltwater estuary systems, tidal plains and mud flats, and a band of paperbark swamps cut across the northern (near-coastal) part of Marrangu country.

1 Spelt 'Mere' by Borsboom (1978a, 1978b), who also spells Marrangu with one ' $r$ ' only. 


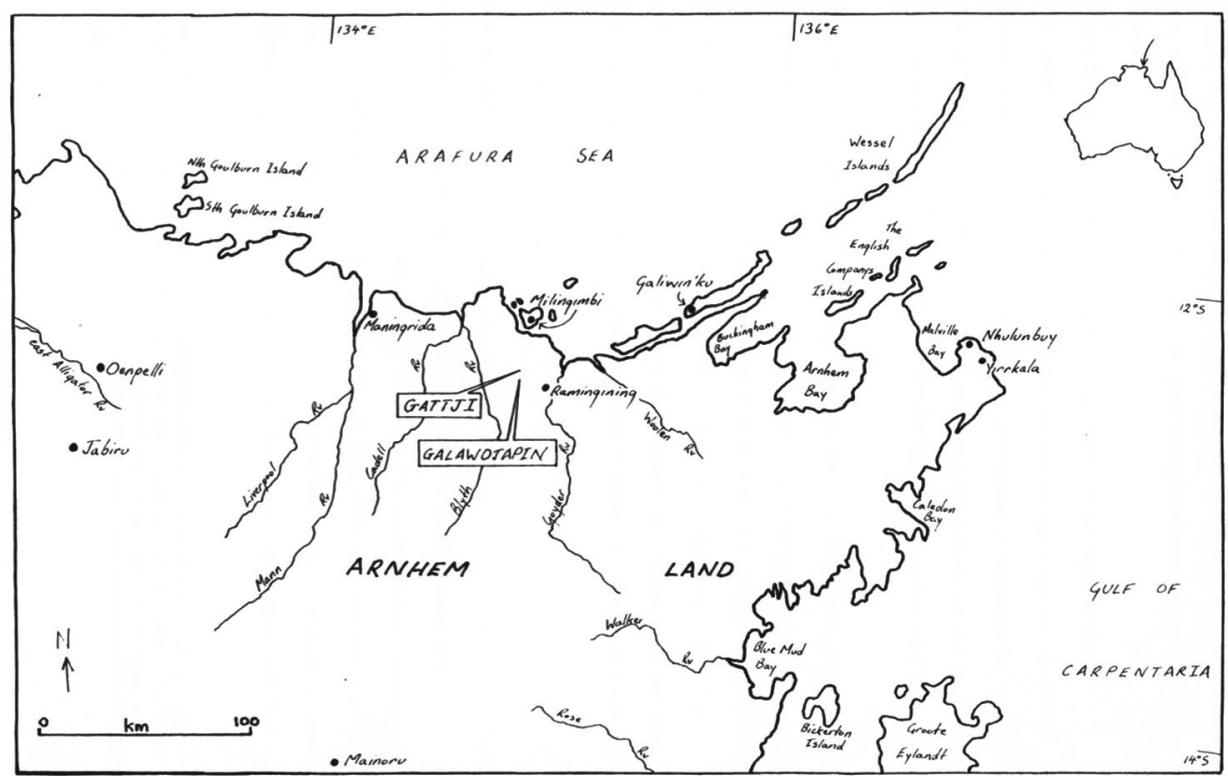

Figure 5.1 Location Map-North-central Arnhem Land, Australia.

Source: Craig Elliott.

The homelands Galawdjapin and Gattji are located beside Gattji Creek. ${ }^{2}$ Gattji is a traditional Wulaki place of residence and is a 'big name' place. ${ }^{3}$ Missionaries from Milingimbi Mission visited Gattji prior to World War II, established a garden there and exchanged goods such as tea, sugar, flour, jam, cloth and tobacco for sacred objects. Gattji and another Djinang outstation, 'Gillere' (Gulidi), were visited by Donald Thomson (see Peterson 1976: 104) in 1936-37. Galawdjapin was established as a homeland much more recently, in 1974. At that time several Marrangu, Mildjingi and Ganalbingu people left Maningrida, where most had been resident since the early 1960s, and moved back to ancestral lands.

Keen (1995) has thoroughly critiqued the inadequacy of simplistic, taxonomical anthropological constructs such as 'clan', 'phratry', 'dialect' and 'tribe' to explain Arnhem Land local organisation. Keen argues much ethnographic description consists of converting conceptual metaphors viewed as 'causal' by the subjects of the ethnography, into the 'symbolic' semantic domain of the anthropological metalanguage (ibid.: 504-5). Examples of this conversion process in Arnhem Land ethnography, Keen argues, are variations of mala into 'clan'; matha as 'dialect group'; and ba:purru as 'phratry' (ibid.: 506-7). Comparing early and

2 The part of this watercourse adjacent to and south of Galawdjapin homeland is named Galawdjapin Creek. 3 While Gattji is on Wulaki country, the contemporary population there is majority Marrangu Djinang. Marrangu people live at Gattji by virtue of (generations of) intermarriage, and thereby are able to 'look after' Wulaki land, their mother's country. 
later analyses, the ethnographic record of Arnhem Land contains anomalies and inconsistencies in the interpretative conversion of Yolngu concepts into anthropological categories (ibid.: 507, Table 1). As an ethnographic region, Arnhem Land is far from unique in exhibiting inconsistency between early and later ethnographers' interpretations of local concepts.

Marrangu Djinang ${ }^{4}$ sociality exhibits layers of interconnected local organisation based on the reference points of language, land, kin and Dreaming narrative. I elucidate these layers with reference to the relevant Djinang terms and the anthropological labels with greatest continuing, albeit contested, currency in the literature. I do so mindful of the undoubted and pervasive inadequacies of the hierarchical anthropological models purporting to represent Arnhem Land concepts, as critiqued by Keen.

The Djinang-speaking Marrangu mala or clan belongs to the Dhuwungi patrimoiety. ${ }^{5}$ The residential population of Galawdjapin and Gattji is made up of the local Marrangu Djinang landowners, their affines, children and individuals from adjacent clan lands who normally intermarry with Marrangu Djinang. Mala whose countries either border, have reciprocal food-gathering rights with Marrangu Djinang people, and/or whose country Marrangu Djinang people djaga ('look after') ${ }^{6}$ are Wulaki, Yalungirri, Djadiwitjibi, Murrungun, ${ }^{7}$ Rembarrnga, ${ }^{8}$ Ganalbingu and Balmbi. Marrangu Djinang people have guardianship rights in the sense meant by Morphy (1984: 28-9) over the territory one of these groups, Rembarrnga, because the original Rembarrnga-speaking mala is extinct. Both Wulaki and Ganalbingu mala intermarry with Marrangu Djinang people, and thus 'look after' their mother's country. This means they have rights to paint their 'mother' clan's Dreamings and are obliged to perform certain ceremonial duties for their 'mother' clan. Other clan countries Marrangu Djinang people 'look after', and call 'mother', are Djadiwitjibi, Mildjingi and Murrungun (all Yirritjing moiety).

\footnotetext{
4 I employ the label 'Marrangu Djinang' in the paper title and throughout mindful of the history and reported inconsistencies of such labels in the ethnographic literature (for example, see Berndt 1976: 145-59; and Keen 1995: 508). The label 'Marrangu Djinang' has some similarities with Berndt's 'mada [matha]-mala pair', in that it combines socio-religious and linguistic elements. It is only in their combination, consistent with the usage in this paper, that Marrangu Djinang denotes a local territory with focal sites and affiliated set of people and sacra. Each term - Marrangu and Djinang - when employed separately has potential to denote a range of additional cultural references.

5 Dhuwungi is the Djinang name for the patrimoiety known in northeast Arnhem Land as Dhuwa or Dua. The Djinang name for the opposite patrimoiety is Yirritjing (known in northeast Arnhem Land as Yirritja). For an account of the Dhuwungi moiety foundational Djang'kawu mythology, see Bagshaw (2008: 33-7).

6 See Berndt (1976: 156) and Keen (1995: 513) for comparable usages of this term.

7 This is a Wulaki-speaking, Yirritjing moiety Murrungun clan, not the Dhuwungi moiety Murrungun clan associated with the Djareware (Wild Honey) Dreaming.

8 'Rembarrnga' is included here in its mala or clan sense. 'Rembarrnga' is also a matha or dialect name.
} 
Marrangu is also the name that identifies the group of mala (clans) that share a single Dreaming track or property (baparru or ba:purru, babaru, bapurru). In the Marrangu case, the shared Dreaming is Djareware or Yarrpany (Wild Honey or Sugar Bag). ${ }^{9}$ Social and ceremonial interconnectedness through baparru is a feature of mala organisation across Arnhem Land (see Morphy 1990: 316; Keen 1995: 514-6; Bagshaw 2008: 32-3), although inclusive interrelationships based upon language (yan), dialect (matha), territoriality and intermarriage (djungkai) djunggayi) and reciprocal ceremonial ties are also significant.

Based on my research with Marrangu Djinang people, the term baparru has a number of applications. Primarily, baparru refers to the aggregate of same-patrimoiety mala that share a Dreaming (or other form of madayin or religious property) and whose countries contain sites named in that story. ${ }^{10}$ At Galawdjapin and Gattji the word baparru- $a$ is further used to denote the gathering of kin at a burial and its associated ceremonies. Others (for example, Berndt 1955: 96; Thomson 1975: 6; Hiatt 1965: 20) have noted interchangeable usages of baparru and mala elsewhere in Arnhem Land, suggesting baparru may mean both the Dreaming-based affiliations of several mala (the sense used here) and the patrilineal landowning group mala. My research at Galawdjapin and Gattji recorded the former usage of baparru, though the term undoubtedly has extended applications (see Keen 1995: 514).

Additional to Marrangu Djinang, the Marrangu baparru consists of Dhuwungi patrimoiety mala with the following names and geographical affiliations: ${ }^{11}$ Murrungun (Raymangirr, near Lake Evella/Gapuwiyak) ${ }^{12}$; Djambarrpuyngu (Elcho Island, Galiwin'ku); Wagilak (Roper River); Burarra (Glyde River); Marrakulu (Trial Bay); and Kulumula (Wessel Islands ${ }^{13}$ ). According to Djinang Marrangu, all these mala may be identifiable as 'Marrangu' and form part of the Marrangu baparru. The mala that make up the Marrangu baparru are geographically widespread, located along the northwesterly journey of the Djareware (Wild Honey) Dreaming track. On this basis, all Marrangu mala are said to share 'one track' and, despite linguistic differences, 'one song'.

\footnotetext{
9 As is explained below, the Marrangu Djinang version of this mythology, Mewal and Djareware Dreaming, is a variation highlighting localised events and interrelationships within this more broadly shared mythology. 10 Keen (1995: 514-5) describes similar applications of the term 'ba:purru'. This kind of configuration has been called 'phratry' by Warner (1937/1958: 33) and 'totemic unions' by Shapiro (1981: 23).

11 I recognise that the labels noted here are not used in an entirely consistent way to denote a singular 'level' of social organisation. Each of the names cited here operates as a linguistic label, as well as being part of mala and baparru formations. For example, Djambarrpuyngu refers to a linguistic unit, a patrifilial group and an aggregation of several patrifilial groups (Peter Toner, personal communication). It is reasonable to say that Arnhem Landers use a range of self-referential names, and a range to refer to others. Each label can, depending on the logic of the social and geographical context, represent a more or less inclusive 'level' of group representation.

12 Clan territory locations are approximations only.

13 Ian Keen (personal communication).
} 
Mala making up the Marrangu baparru exchange closely related and ceremonially powerful sacred property (madayin), such as names, songs, ceremonial acts and objects, between each other, and direct ceremonies such as mortuary rites on each other's behalf. The high value placed upon knowledge and ownership of such property (designs, sand sculpture, ceremonies and songs) means these exchanges are an important expression of both mala autonomy and baparru interconnectedness. Taylor (1987: 381) has observed that baparru is a highly abstract concept with little bearing upon on-the-ground groupings, but that baparru relations between mala highlight the notion that spiritual unity transcends geographic, political and linguistic differences. Mala within the same baparru do not share in toto the same Dreaming property as each other. Along their shared Dreaming track, each mala highlights (in song and ceremonies) mythic aspects most relevant to themselves and their country. Marrangu Djinang emphasise that part of the Djareware's journey that occurs along Djimbi Creek. Similarly, while both Djambarrpuyngu and Marrangu Djinang sing Stringybark tree manikay, each emphasises slightly different aspects. This custom is typically described as 'same but different' - a feature axiomatic of baparru relations in Arnhem Land.

Other names, all referencing local cosmology, regarded as uniquely identifying Marrangu Djinang mala are Warnambi, Wurrkiganydjarr, ${ }^{14}$ Mewal and Mungurrpi. Warnambi and Wurrkiganydjarr both relate to the Stringybark tree; Warnambi to the tree itself while Wurrkiganydjarr denotes 'stringybark flower' (Borsboom 1978b: 28). Literally, 'wurrkiganydjarr' translates as 'flower power', 'wurrki' means flower while 'ganydjarr' means 'power, ability, strength, stamina' (Waters 1983: 41, 114). ${ }^{15}$ Mewal, the Spirit Being companion of Djareware, is a term used by others to address Djinang Marrangu people in public spaces, such as at nearby Ramingining. The rarely employed fourth term, Mungurrpi, refers to Marrangu Djinang people at Galawdjapin.

The Marrangu Djinang mala is made up of 'bottom' and 'top' parts or companies, known as Nongere (or Mongon or Mongonirri) and Guraknere, respectively, with roughly similar numbers. ${ }^{16}$ Most Nongere individuals live at Galawdjapin and Gattji; and most Guraknere (or 'top') Marrangu Djinang reside at or near Ramingining. The division has a mythological foundation, when the Djareware

14 Spelt 'Wurgigandjar' by Borsboom (1978a, 1978b).

15 The name 'Wurrkiganydjarr' was given to the Djinang Marrangu people by another clan, the Djambarrpuyngu-speaking Marrangu clan (Borsboom 1978b: 28).

16 Taylor's Kunwinjku informants translated the word 'company', in the context of intra-clan division, as 'follow each other', 'mix together', 'we share' and 'all one family' (1987: 86-7). I received virtually identical glosses relating to Nongere and Guraknere. Additional to intra-clan divisions, however, 'company' is frequently used by Marrangu people to describe intermarrying clans (that is, between clans in a 'mother' or djungkai relationship). There is some crossover in these two senses of 'company', since the intra-clan Nongere and Guraknere subgroups structure marriage arrangements with djungkai clans. See also Keen's (1978: 214) findings concerning 'company' usage at Milingimbi. 
(Honey) Being used a stone axe to cut Marrangu country into two parts, thus forming Nongere and Guraknere (Borsboom 1978b: 72). The interrelationship is further imaged in body metaphor, in that Guraknere means the neck or apex of the spine (hence 'top') while Nongere denotes the 'bottom' of the spine. ${ }^{17}$ Both Nongere and Guraknere contain sites connected with Djareware Dreaming and both are considered owners of all Marrangu Djinang land and the spiritual property associated with it, but each differs in relationship to neighbouring clans. For example, Nongere Marrangu is adjacent to Wulaki country, whereas Guraknere Marrangu country, to the southeast, adjoins Ganalbingu country. Nongere Marrangu marry with the Wulaki-speaking mala named Djelaworwor, and are thus djungkai for Wulaki country, whereas Guraknere Marrangu marry with their Ganalbingu-speaking neighbours and have djungkai responsibilities towards Ganalbingu mala territory.

\section{Mewal and Merri in Marrangu Djinang Cosmological Landscapes}

Merri and Mewal are anthropomorphic spirit beings believed to inhabit the Marrangu Djinang landscape, and are attributed significations in ceremonial practices, especially mortuary rites, and bodily experience. The local founding narrative in Marrangu Djinang belief is the Mewal and Djareware (Wild Honey) Dreaming. In this mythology, Mewal, imaged as part bee and part woman, collected honey in Marrangu Djinang country (as people continue to do). As a substance containing eggs, in Marrangu belief honey contains 'spirit children', and therefore conceptive power. Mewal is also an emblem of Marrangu Djinang origins, identity and continuity, through transformative acts such as the designation of places in Marrangu country as 'Mewal' sites; the symbolic use of white down body decoration in Marrangu ceremonies; and in the Mewal ceremonies (bunggul), enacted during mortuary rites, where the deceased's bones become emblems of ancestral and clan regeneration. The Djareware Dreaming unites all Marrangu clans but Mewal, as an entity within this mythic tradition specific to Marrangu Djinang, highlights the clan's identity within overall baparru organisation.

But Mewal is not all 'good' in Marrangu Djinang cosmological symbolism. Mewal is 'bad, but him not all bad', as revered Marrangu ancestor Dick Miwirri (now deceased) once told me. In the Mewal and Djareware Dreaming, Mewal inhabits monsoonal jungles. These localised landscapes are both impenetrable

17 Body imagery as metaphors for social group constitution and reproduction are elaborate and pervasive in Arnhem Land; see Keen (1978: 281-334; 1995: 509-13). 
physical environments and symbolically unsocialised, malignant realms in Marrangu cosmology. The significance of Mewal as founder of clan identity is thus multilayered, complicated by association with these symbolically malign cosmological 'landscapes'. Mewal joins Merri, the other Marrangu Djinang anthropomorphic spirit being, to roam in the jungle at night, making distracting sounds so people lose direction. In this form, Mewal is believed a corruption of the human body, ugly, deformed or skeletal only. In behaviour this Mewal is asocial, and, like Merri, evokes negative sentiments associated with the physical (and cosmological) jungle environment. Alongside this, Mewal is believed to have interacted congenially with the earliest human beings, teaching them and bestowing rights in songs ${ }^{18}$ and dances (that is, madayin property). The belief that words in manikay (clan songs) are learnt from the spirits of the dead exemplifies this interaction.

There are 13 Marrangu Djinang manikay song subjects. The manikay songs celebrate the actions of Dreaming (Wangarr) beings including, in the present case, Djareware, Mewal and Merri.${ }^{19}$ In manikay performance, each song consists of formulaic recitations of name words ${ }^{20}$ that connote interrelationships within Marrangu Djinang land and cosmology. The 13 Marrangu Djinang manikay songs are sung in a consistent (though, in practice, rarely identical) order and are thematically grouped, shown in Table 5.1. The left-hand column lists the 13 Marrangu Djinang manikay song subjects ${ }^{21}$; the centre column shows groupings as described to the current author; and the right-hand column shows Borsboom's 'sub-clusters' of the same song cycle.

The manikay subjects relate to cosmological categories and 'top to bottom' ecological sectors within Marrangu Djinang country. The 'Mewal songs' (centre column) and Borsboom's 'Gravel sub-cluster' (right column) include subjects associated with the driest and most inland Marrangu country, dominated by stringybark trees, the flowers (wurrki) of which provide pollen for honeybees. The 'Gapi' or Water group of songs cover subjects associated with wetland parts of Marrangu country-fish species and wet season rains and floodwater. My 'ungrouped' and Borsboom's 'Jungle' sub-cluster includes entities found in monsoonal thickets, or believed to inhabit parallel cosmological realms,

18 As Keen noted, the Liyagalawumirr clan also has a song subject named Mewal (author's fieldnotes).

19 See Clunies Ross (1978: 129) for an overview of the manikay song genre of Arnhem Land song.

20 These name or song words are often not found in everyday discourse, and therefore not all are to be found in dictionaries of the Djinang language (such as Waters 1983). This song word characteristic is typical of Arnhem Land song (see Hiatt and Hiatt 1966: 2) and indeed, of song in oral traditions worldwide (see Merriam 1964: 189).

21 The 13 manikay song subjects do not represent the entire corpus of Marrangu Djinang Dreamings - there are other significant Marrangu cosmological entities not represented in the manikay cycle. These include, for example, Bullia (saltwater catfish), Dupun/Bardurru (hollow log), Bordjirrai (forked stick), Mulitji (fish trap), Warbalulu or Murla (pelican), Djarrka (freshwater water goanna), Ragi (lily root) and several Cloud Dreamings. 
in the mid-zone of Marrangu land. In these dense forest areas, such as at Djambi and Bumbaldjarri, freshwater creeks meet swampy, seasonally flooding lowlands. ${ }^{22}$ However, the four 'ungrouped' manikay (Table 5.1, centre column) are not structured by any single cosmological or ecological characteristic but are transitional motifs, and thus positioned in the song cycle between 'Mewal' and 'Gapi' songs. The cycle abides to the 'most typical' associations (Borsboom 1978b: 74), with the less typical linkages as the transitional motifs. Marrangu people recognise the unity of the cycle overall. This is evidenced in statements that all manikay are 'Our Dream', reflecting an understanding that the complex interrelationships between the manikay songs bind the cycle together.

Table 5.1 Groupings of Marrangu Djinang manikay song subjects.

\begin{tabular}{|c|c|c|}
\hline $\begin{array}{l}\text { Marrangu Djinang Manikay } \\
\text { song subjects }\end{array}$ & Author's sub-groupings & $\begin{array}{l}\text { Borsboom's sub-clusters } \\
\text { (1978a: 114; 1978b: 71). }\end{array}$ \\
\hline & Mewal songs & 'Gravel' sub-cluster \\
\hline 1. Gundui (Stringybark Tree) ${ }^{a}$ & Gundui (Stringybark Tree) & Gundui (Stringybark Tree) \\
\hline 2. Djareware (Wild Honey) & Djareware (Wild Honey) & Djareware (Wild Honey) \\
\hline 3. Geganggie (Friar Bird) & Geganggie (Friar Bird) & Geganggie (Friar Bird) \\
\hline 4. Wak Wak (Crow) & Mewal (Spirit Being) & Wak Wak (Crow) \\
\hline \multirow[t]{2}{*}{ 5. Mewal (Spirit Being) } & Merri (Spirit Being) & \\
\hline & Ungrouped & 'Jungle' sub-cluster \\
\hline 6. Merri (Spirit Being) & Wak Wak (Crow) & Mewal (Spirit Being) \\
\hline $\begin{array}{l}\text { 7. Djudo-Djudo } \\
\text { (Tawny Frogmouth) }\end{array}$ & $\begin{array}{l}\text { Djudo-Djudo } \\
\text { (Tawny Frogmouth) }\end{array}$ & Merri (Spirit Being) \\
\hline 8. Narge Narge (Possum) & Narge Narge (Possum) & $\begin{array}{l}\text { Djudo-Djudo } \\
\text { (Tawny Frogmouth) }\end{array}$ \\
\hline \multirow[t]{2}{*}{ 9. Gulwirri (Cabbage Palm) } & Gulwirri (Cabbage Palm) & Narge Narge (Possum) \\
\hline & Gapi songs & 'Water' sub-cluster \\
\hline 10. Morgal (Mud Cod) & Morgal (Mud Cod) & Gulwirri (Cabbage Palm) \\
\hline 11. Wudurbal (Bream) & Wudurbal (Bream) & Morgal (Mud Cod) \\
\hline 12. Bara (northwest Monsoon) & Wunggutj Gapi (Floodwater) & Wudurbal (Bream) \\
\hline 13. Wunggutj Gapi (Floodwater) & Bara (northwest Monsoon) & Wunggutj Gapi (Floodwater) \\
\hline & & Bara (northwest Monsoon) \\
\hline
\end{tabular}

a Alternate Djinang names for stringybark trees are balatj, bemborlai or dirrka.

22 As White (2003: 193-9) has observed, Arnhem Land cultural landscapes and aesthetics are complex and do not parallel Euro-Australian notions of beauty. Rather than visual appeal, it is the sacred character of a place that, in Yolngu thought, makes a place significant and memorable. In the case of Djambi and Bumbaldjarri, they are highly significant in Marrangu Djinang belief because of their centrality in manikay and Djareware mythology, despite being mosquito-infested, swampy and largely impenetrable. 
The 'Mewal songs' and 'Gapi songs' manikay groupings reference two important mythic narratives in Marrangu cosmology: Mewal and Djareware Dreaming (discussed above) and Bullia-Gapi Dreaming. The latter mythology, Bullia (Saltwater Catfish) and Gapi (Water), references the final phase of Marrangu Djinang mortuary rites known as Bardurru (or Dupun or Larrgan), when crushed bones of the deceased are placed in a hollow log coffin. In Bullia-Gapi Dreaming, seasonal floodwaters (Wunggutj Gapi) inundate the coastal plains, filling fresh and saltwater creeks where fish species-Wudurbal (bream) and Morgal (mud cod)-live. These fish, which in Marrangu belief symbolise wuguli (birrimbirr) eternal spirits of the dead, are caught in mulitji (fish traps) imaged as a pelican's (warbululu) gullet. Mulitji and warbalulu are cosmologically associated with the northwest horizon, the direction of monsoonal rains (Bara) and location of Gorriba Island, spiritual home for deceased Marrangu individuals and the Merri Spirit Being named Luma Luma. Bullia is not a named Marrangu manikay song subject, ${ }^{23}$ but is a conception Dreaming in Marrangu belief. The BulliaGapi Dreaming is thus highly significant in Marrangu eschatological beliefs and associated mortuary practices.

That Mewal (and Merri) appear in different groupings in the typologies (see Table 5.1) highlights that there are two shifting aspects to the Mewal spirit being: Mewal is the Dreaming creator allied with Djareware; and, additionally, a malign jungle spirit that interacts with Merri and spirits of the dead. Through this polysemy Mewal is a symbol conveying the idea of ancestral regeneration after death - a pivotal theme of the extended mortuary customs in north-central Arnhem Land. In this Mewal is closely analogous with wuguli, the immortal spirit aspect in Marrangu Djinang belief, that survives death and returns to clan country or to a spirit realm with physical referent (Gorriba Island).

While sharing a jungle landscape and some associated attributes, the Merri spirit (in both its 'dead body' and jungle form), and in partial contrast with Mewal, is a concept conveying unsettling ideas about mortality, daily human experience and bodily well-being. For example, mishaps and bad dreams are blamed on Merri's diffuse, unpredictable and malignant presence in the landscape, especially in local monsoonal jungle thickets and at night. As 'dead body' spirit, Merri is held to exist somewhere between lived and Dreaming realities. Merri is associated with bodily attachment and the decay of a corpse immediately after death. Merri spirits are thought an anathema to the continuity of social stability and individual life: they are believed to alter paths, foot tracks and landforms, cause disputation, interrupt conception processes and intercept wuguli spirits of the deceased, thus preventing ancestral reunion. Merri has

23 On one performance occasion during research, however, I was told that Bullia (or Djikada) was sung as a separate manikay subject (Elliott 1991: 100). 
the further aspect of 'dead body' spirit and spirits of the longer-term dead who live at Gorriba (an 'island of the dead' off the north-central Arnhem Land coast). The cosmological significance of Gorriba Island with 'dead body' spirits parallels the association of Djambi and Bumbaldjarri, the main two monsoonal jungle sites within Marrangu country. Mewal, on the other hand, is not involved in unsettling daily experience and is considered more benign, independent, transcendent and intangible than Merri. Without overdrawing the contrast, in Morphy's (1990: 313) terms Mewal is closer to a Creator Being whereas Merri more resembles an Inheritance Being.
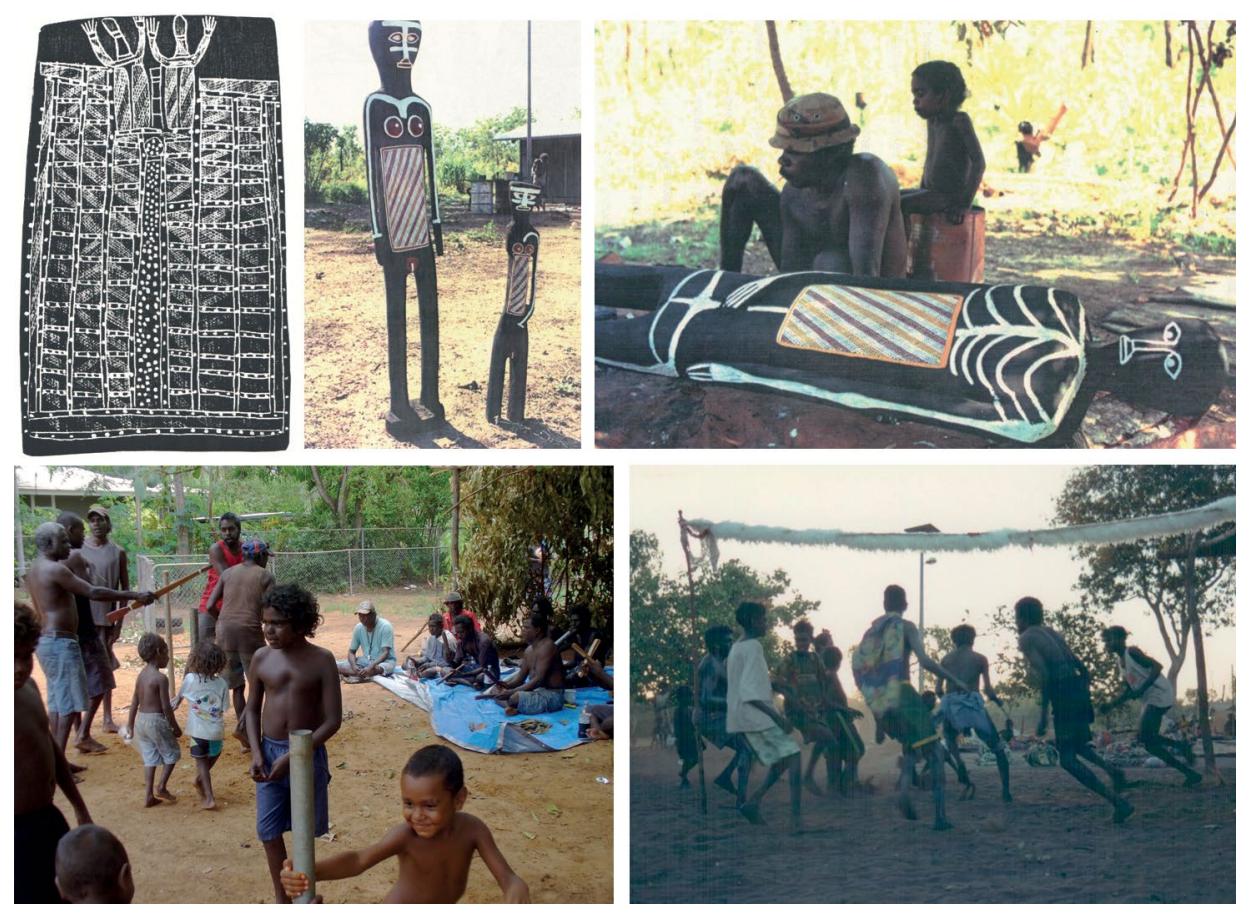

Figure 5.2 Merri and Mewal in Marrangu Djinang art and ceremony.

Top left: Bark painting showing (at top) the two spirit women 'Miwal' (Mewal) and 'Wanu-wanu' collected at Milingimbi in 1948 (in Mountford 1956: 390). The long panel in the middle is the central pole supporting the bark hut built by the two spirit women at 'Djimba' (Djimbi Creek). Inside the panel the dots represent bees and honeycomb. Top middle: Two sculptures representing Merri as a mother and daughter pair produced by George Putti (deceased) at Galawdjapin Homeland in 1989. The cross-hatching, termed gumununggu, is the Marrangu Djinang design for Merri. Top right: Sculpture representing Merri as a 'dead body' spirit produced by Andrew Margululu (deceased) at Galawdjapin Homeland in 1989. The gumununggu cross-hatching on stomach is complemented by skeletal 'ribs' on the chest. Bottom right: Marrangu Djinang bunggul (song with dance) enacting mythology where Mewal searches for Djareware (honey) following honeybees from Raymangirr in Marrangu Murrungun country, northeast Arnhem Land. The white line hanging above the dancers represents flying honeybees. This bunggul occurred during the wirgugu (wake) for an elder Marrangu Djinang man, Gattji, 1995. Bottom left: Marrangu Djinang perform Mewal bunggul at Ramingining in January 2013. This bunggul occurred during the wirgugu (wake) for a senior Marrangu Djinang man.

Sources: Bark painting: C.P. Mountford (Melbourne University Press); all photos: Craig Elliott. 
As jungle spirit, Merri exists in various forms: in human form, usually with a deformity or as a child; in animal form (as flying fox, native cat or frog); or as an incorporeal 'ghost'. The 'dead body' Merri is identified with the putrefying corpse and the 'homeless' wandering spirit believed to separate from the body at death. At death this wandering spirit is thought acutely dangerous, as it hopelessly tries to return to the living community. This 'dead body' Merri spirit is believed to be encountered in dreams of violence and disaster, and to cause accidents, arguments and physical ailments. With the passing of time the 'dead body' spirit withdraws from the living and joins other spirits of the dead at Gorriba and in the jungle landscapes, shedding identity with the deceased individual in the process, though not entirely - the 'dead body' Merri spirit may withdraw but continues visiting places and people associated with the deceased.

A further significant quality of Merri (especially in its most 'concretely' malignant 'dead body' spirit aspect) follows from its recognised form and unique position in Marrangu ontology. Merri is a highly effective and valued socialising agent, orienting individuals towards sanctioned behaviours and roles from an early age. Children soon learn to fear wandering in the dark alone because when they do adults point and shout 'merri' (or 'mokuy') and hold aloft a buffalo skull. Children quickly connect these actions with danger. Merri operates to legitimate the positive value placed on community and family bonds because emotional or mental disturbance and antisocial behaviour (e.g. eating alone, walking alone, sulkiness, silence) is accounted for as a malign predilection brought on by the agency of Merri. This is a culturally preferred explanation that avoids blaming an individual.

The contradictions and ambiguities in the attributions, significations and interrelationships between Merri and Mewal demonstrate the importance of these figures in Marrangu cosmology, ontology, geography and socialisation. Mewal and Merri are an important but not all-inclusive component of Marrangu Djinang thought. There are many more Dreaming beings and relationships involving different Marrangu cosmological entities.

\section{Accounting for Ambiguity and Form in Mewal and Merri Beliefs}

The Mewal and Merri spirit beings occupy different but shifting and overlapping positions in Marrangu Djinang cosmology. There are cultural, geographical and historical demographic reasons that account for the ambiguities in the significations of Mewal and Merri in Marrangu thought. Mewal and Merri interpenetrate across aspects of cosmology, landscape, the life cycle 
and daily experience. Mewal and Merri do not correspond, in any singular straightforward way, with visible (or invisible) referents. Mewal and Merri are conceptually similar symbols which may at times have an acknowledged physical manifestation. At other times they do not. In these circumstances, discrepancies in the significations people attribute to them are apt to arise. People do not point to objects, in the way they can for honeybees or Stringybark trees, and say 'that is Merri' or 'that is Mewal'. Only by recognised and shared symbolic association can, for example, a corpse or a carving be called 'Merri'; or skeletal remains or a painting of a human female collecting honey be called 'Mewal'.

Geography and demography partially accounts for ambiguities and localised coalescence of cosmological beliefs. Galawdjapin and Gattji homelands, with predominantly Marrangu Djinang and Wulaki speakers, respectively, are two kilometres apart. The interpenetration of Marrangu Djinang and Wulaki belief systems is evident in the case of Mewal. Wulaki cosmology recognises a Being named Ganingalkngalk and Wulaki speakers sometimes use the Marrangu term 'Mewal' to describe their Being. Like Mewal, Ganingalkngalk is both a creator Being and a malevolent jungle entity: for example, Ganingalkngalk created Gattji lagoon, an important Wulaki clan site; elsewhere in Wulaki cosmology Ganingalkngalk is a jungle-living 'meri' with responsibility for the 'larkan' hollow log coffin (see Thomson [Peterson] 1976: 103). Similarly, at Ramingining and Milingimbi, Djinang speakers use the Gupapuyngu words mokuy coterminously with Merri; and birrimbirr as an alternative for the Djinang term wuguli.

Post-war demographic change in Arnhem Land, chiefly to mission-or governmentestablished communities, has increased the diffusion of concepts from other regional dialects and languages (interaction with Gupapuyngu at Milingimbi, Kunwinjku at Maningrida, or Rembarrnga at Beswick, for example). Borsboom cites the case of a Marrangu Djinang man who had, after years living at Bamyili on the Beswick (70 kilometres east of Katherine) acquired the Rembarrnga language word 'Bolung' which he applied, seemingly without contradiction, to both Merri and Djareware (Borsboom 1978b: 54-5). This acculturation processaided by demographic and linguistic factors, leading to the incorporation and consolidation of names, categories and episodes, and extension of existing beliefs - has a long history in northern Australia. ${ }^{24}$

In part due to the introduction of Christian mission-derived oppositional ideas ('body' and 'soul', 'heaven' and 'hell') local cosmological concepts have become less internally differentiated and nuanced, with certain scenarios being truncated and consolidated with others. For example, the Merri being named Luma Luma of Gorriba Island has its own Dreaming scenarios and associated

24 For example, Macknight (1980: 139-40) cites the introduction of Papuan burial customs in the Tiwi Islands; and Warner describes use of Macassan designed masts in 'Murngin' mortuary rites (1937/1958: 433). 
sites and ceremonies, but respondents often claimed the Luma Luma Merri was simply a synonym for either the 'dead body' Merri of the recent dead, or of the longer-term dead. Finer correlations remain existent, but the process of historical syncretism is leading to a less elaborately integrated and increasingly imprecise framework of eschatological speculations. The scope of the Merri figure in Marrangu eschatology has, superficially at least, been simplified as a result of assimilation with Christian notions. Marrangu people see no contradiction in the incorporation of Christian ideas within their own cosmology. In the idiom of Aboriginal English, both sets of beliefs are viewed as 'straight', containing truth and 'the Law'. People at Galawdjapin and Gattji profess their belief in Christianity to be a harmonious adjunct to Marrangu cosmology. There is no sense in which Christian ideas are seen as incompatible with local cosmological categorisations.

There is evidence from elsewhere in Aboriginal Australia that the process of systematic investigation itself has highlighted ambiguities in Indigenous beliefs that are of little concern to believers themselves. Stanner (1963: 260), in his investigation of Murinbata 'pure', 'clan' and 'creature' spirits, observed that 'there was no difficulty in getting the Murinbata to agree that their traditions left much unclear, but the conflicts were evidently of little interest to them'. He goes on, noting how systematic enquiry led to the unearthing of apparent inconsistencies in Murinbata belief:

All the mythic personages seemed clear cut in ordinary conversation but lost outline or became shadowed by ambiguity under closer study. It seemed to me precisely that property which allowed both their mythological and ritual development ... Eventually I saw the wisdom of not forcing the ideas to a precision that was not in them. (p. 265)

Clunies Ross and Hiatt, too, in the case of mythic interpretations of a ground sculpture at a Gidjingali Larrgan (Bardurru) mortuary ceremony, found an insistence on coherent interpretations forced ambiguities to come to light where they 'might never have become overt' (1977: 139). My hosts at Galawdjapin and Gattji fielded my enquiries, though few professed an appetite to investigate the ambiguities of Mewal and Merri. The belief that Mewal and Merri exist, as evidenced by transformations in Marrangu cosmology and country, manikay and ceremony, was proof and knowledge enough. A closely related point here is Keen's recognition that there is a fundamental difference between objectivising anthropological analyses of concepts, on one hand, and Yolngu ontological commitment to the reality of, or living with, those concepts (1995: 505) on the other. Researchers' repeated and understandable inquiries about conceptual meaning, based on our analytical drive to explain ambiguities and generate valid generalisations, contain no ontological commitment actually to live with those concepts, rich ambiguities and all. 


\section{Conclusion}

Cosmological categorisations are an arena of human thought and practice marked by indeterminacy, interpenetration of ideas and dynamic change. This is especially so in oral traditions, but Judeo-Christian traditions exhibit similar characteristics. Consider, for example, the historical diffusion of alternate imaginings concerning angels, saints, devils and demons. In Arnhem Land, cosmological beliefs do not constitute fully integrated and harmonious encapsulations of socio-religious reality. Marrangu Djinang cosmology is not a unified, fully integrated body of beliefs. Other Yolngu clan cosmologies have been characterised as 'chunks' or 'heaps' of Dreaming scenarios 'lumped together' (Morphy 1990: 326; see also Keen 1987: 103). The aptness of these terms is arguable as they may suggest indiscriminate selection. It is true that Djinang Marrangu cosmological beliefs place profound, transformative episodes alongside seemingly inconsequential events, significant elements contrasting sharply with those of (apparently) less weight. It is not a stabilised, all-encompassing system admitting only singular, coherent or complete interpretations. Marrangu Djinang manikay, for instance, is a selective extrapolation of thematically linked and proximately grouped Dreaming entities, drawn from a larger and richer corpus of potential mythic scenarios and emblems.

Conceptual dynamism in belief systems engages change and active ambiguity as an explanatory device. This process produces contradictory interrelationships, not seamless integration. Conceptual ambiguity and semantic dynamism are features of Marrangu Djinang cosmological and social categories. Mewal and Merri overlap considerably in Marrangu Djinang cosmology, art, song, mortuary beliefs and practices, lifecycle beliefs and, perhaps most significantly, in the cultural landscape. The coalescence of these ideational, ceremonial, experiential and geographic realities makes finding precise contextual denotations difficult. This analysis bears out Ian Keen's findings (1977, 1978, 1994, 1995) that the creation and reproduction of Yolngu social meanings are buttressed by conceptual indeterminacy and ambiguity, features that are integral to Arnhem Land religion, and religious traditions more broadly.

\section{References}

Bagshaw, G. 2008. The physical and cultural dimensions of the Yalangbara area. In M. West (ed.), Yalangbara: Art of the Djang'kawu, pp. 31-44. Darwin: Museum and Art Gallery of the Northern Territory.

Berndt, R.M. 1955. 'Murngin' (Wulamba) social organization. American Anthropologist 57: 84-106. 
Berndt, R.M. 1976. Territoriality and the problem of demarcating sociocultural space. In N. Peterson (ed.), Tribes and Boundaries in Australia, pp. 131-61. Canberra: Australian Institute of Aboriginal Studies.

Borsboom, A.P. 1978a. Dreaming clusters among Marrangu clans. In L.R. Hiatt (ed.), Australian Aboriginal Concepts, pp. 106-20. Canberra: Australian Institute of Aboriginal Studies.

Borsboom, A.P. 1978b. Maradjiri: A Modern Ritual Complex in Arnhem Land, North Australia. PhD Thesis, Katholieke Universiteit, Nijmegen.

Borsboom, A.P. 2011. Yolngu ways of knowing country. Paper presented at 'Barks, Birds and Billabongs: An International Symposium Exploring the Legacy of the 1948 American-Australian Scientific Expedition to Arnhem Land'. Canberra: National Museum of Australia.

Clunies Ross, M. 1978. The structure of Arnhem Land song-poetry. Oceania 49: $128-56$.

Clunies Ross, M. and L.R. Hiatt. 1977. Sand sculptures at a Gidjingali burial rite. In P.J. Ucko (ed.), Form in Indigenous Art, pp. 131-46. Canberra: Australian Institute of Aboriginal Studies.

Elliott, C.N. 1991. 'Mewal is Merri's Name': Form and Ambiguity in Marrangu Cosmology, North Central Arnhem Land. MA Thesis, The Australian National University, Canberra.

Hiatt, L.R. 1965. Kinship and Conflict: A Study of an Aboriginal Community in Northern Arnhem Land. Canberra: Australian National University Press.

Hiatt, L.R. and B. Hiatt. 1966. Notes on Songs of Arnhem Land [accompanying booklet]. Canberra: Australian Institute of Aboriginal Studies.

Keen, I. 1977. Ambiguity in Yolngu religious language. Canberra Anthropology 1(1): 33-50.

Keen, I. 1978. One Ceremony, One Song: An Economy of Religious Knowledge among the Yolngu of North-East Arnhem Land. PhD Thesis, The Australian National University, Canberra.

Keen, I. 1987. Review of Journey to the Crocodile's Nest. Canberra Anthropology 10(1): 102-4.

Keen, I. 1994. Knowledge and Secrecy in an Aboriginal Religion: Yolngu of NorthEast Arnhem Land. Oxford: Clarendon Press. 
Keen, I. 1995. Metaphor and the metalanguage: 'groups' in north-east Arnhem Land. American Ethnologist 22(3): 502-27.

Macknight, C.C. 1980. Outback to outback: the Indonesian archipelago and northern Australia. In J.J. Fox (ed.), Indonesia: The Making of a Culture, pp. 137-47. Canberra: Research School of Pacific Studies.

Merriam, A.P. 1964. The Anthropology of Music. Evanston, IL: Northwestern University Press.

Morphy, H. 1984. Journey to the Crocodile's Nest. Canberra: Australian Institute of Aboriginal Studies.

Morphy, H. 1990. Myth, totemism and the creation of clans. Oceania 60(4): $312-28$.

Mountford, C.P. 1956. Art, Myth and Symbolism: Records of the AmericanAustralian Expedition to Arnhem Land, 1948, vol. 1. Melbourne: Melbourne University Press.

Shapiro, W. 1981. Miwuyt Marriage. Philadelphia: Institute for the Study of Human Issues.

Stanner, W.E.H. 1963. On Aboriginal religion, VI: cosmos and society made correlative. Oceania 33(4): 239-73.

Taylor, L. 1987. 'The Same But Different': Social Reproduction and Innovation in the Art of the Kunwinjku of Western Arnhem Land. PhD Thesis, The Australian National University, Canberra.

Thomson, D. 1975. The concept of 'marr' in Arnhem Land. Mankind 10: 1-10.

Thomson, D. [Peterson, N.]. 1976. Mortuary customs of northeast Arnhem Land: an account compiled from Donald Thomson's fieldnotes. Memoirs of National Museum of Victoria 37: 97-108.

Warner, W.L. 1958. A Black Civilization. Revised edition. New York: Harper and Brothers. (Original work published 1937).

Waters, B. 1983. An Interim Djinang Dictionary. Darwin: Summer Institute of Linguistics.

White, N. 2003. Meaning and metaphor in Yolngu landscapes, Arnhem Land, northern Australia. In D. Trigger and G. Griffiths (eds), Disputed Territories: Land, Culture and Identity in Settler Societies, pp. 187-205. Hong Kong: Hong Kong University Press. 
This text is taken from Strings of Connectedness: Essays in Honour of Ian Keen, edited by Peter Toner, published 2015 by ANU Press, The Australian National University, Canberra, Australia. 